\title{
THE SOCIAL ADJUSTMENT OF CHILDREN FROM HOMELESS SHELTERS: AN AREA OF APPLICATION OF CRITICAL REFLEXIVITY IN SOCIAL WORK

\author{
Kateřina Glumbíková ${ }^{1}$, Alice Gojová ${ }^{2}$, Soňa Vávrová ${ }^{3}$, Barbora Gřundělová ${ }^{4}$
}

\begin{abstract}
On a global scale, the number of families with homeless children is growing. Foreign research shows that homelessness is linked to social adjustment problems. In the Czech Republic there are no surveys on social adjustment in the homeless children population. This article presents partial data from a research survey focused on the situation of homeless mothers with children residing in shelters. The article aims to find out how mothers residing with their children in homeless shelters in the city of Ostrava interpret the social adjustment of their children. The research strategy is qualitative, based on a participatory approach (cooperation with two peer researchers). 33 interviews and 6 focus groups were implemented as part of the research. The research findings also point to a close link between the situation of homelessness and social adjustment of homeless children in the Czech environment, namely as a result of the necessity of socialization in a specific environment with negative consequences on the parenting style and success in school of the children combined with their experience of domestic violence. The research findings imply in practice the need to apply the concept of critical reflexivity in social work with children from homeless shelters.
\end{abstract}

UDC Classification: 304; DOI: http://dx.doi.org/10.12955/cbup.v6.1215

Keywords: homelessness, children, shelter, social adjustment, critical reflexivity

\section{Introduction}

The number of homeless families with children is the fastest growing population of homeless people (Powell, 2012). According to the U. S. Conference of Mayors Report (2006) more than $40 \%$ of homeless people are families with children. The mentioned percentage of mothers with children corresponds with data from the Czech Republic. The Salvation Army ${ }^{5}$ conducted a survey with service users in its shelters in 2015 (Salvation Army, 2016), and it emerged that 38.5\% from the total number of service users were mothers. In relation to worrying numbers of children growing up outside their natural social environment (i.e. homeless children) it is necessary to concentrate our attention to support their positive development.

The connection between the state of being homeless and social adjustment disorders has been proven by a great deal of foreign research (see, e.g. Anooshian, 2005). In the Czech Republic, research into the social adjustment of the population of homeless children is absent. In the context of the aforementioned fact, we conducted the first exploratory study into the life of homeless mothers and their children, which was part of a broader survey. The aim of this article is to describe the situation of children from homeless shelters through the optics of their mothers' narratives in the context of social adjustment and, based on that, to give recommendations for the practice of social work with children from homeless shelters.

\section{Theoretical basis}

Social adjustment can be understood as (1) an ability or as (2) a process. The first interpretation of social adjustment focuses on the ability of individuals to act socially, maintain and enjoy their relationships (Hirschfeld et al, 2000), possibly to find their proper place in the social environment, which is consistent with their age and culture. The second approach sees social adjustment as the process thanks to which people keep an equilibrium among various needs or between their needs and obstacles in their environment (Novotný, 2015). Nilson (2007), whose approach we support, considers social adjustment as a complex and multi-dimensional process, which consists of mutually related phenomena such as coping, emotions, subjective sense, integration, adaptation, support, family focus and focus on the process. The level of social adjustment usually reflects the extent to which the children get on with their peers or their ability to achieve personal goals in social interactions and maintain healthy relationships across time and situations (Reiter \& Lapidot-Lefler, 2007).

\footnotetext{
${ }^{1}$ Faculty of Social Studies, University of Ostrava, katerina.glumbikova@osu.cz

${ }^{2}$ Faculty of Social Studies, University of Ostrava, alice.gojova@osu.cz

${ }^{3}$ Faculty of Social Studies, University of Ostrava, sona.vavrova@osu.cz

${ }^{4}$ Faculty of Social Studies, University of Ostrava, barbora.grundelova@osu.cz

${ }^{5}$ One of the biggest providers of social care for homeless people in the Czech Republic.
} 
The factors which lead to disturbed social adjustment include parents' divorce or their broken relationship, physical attacks ${ }^{6}$, impaired relation to parents (disturbed emotional bonding), frequent moves in their childhood, family abuse or growing up in a disadvantaged environment (see e.g. Ponizovsky et al, 2011). The factors mentioned above are very often accumulated with the children having no permanent home leading to our expectations of a high possibility of disturbed social adjustment.

We distinguish between two types of factors which affect social adjustment: external and internal. External and internal resources work in a certain social context (sitution), which can increase or reduce their effect. In connection with the cited Lipschitz-Elhawi \& Izhaky (2005), they inform us that the longer the period of residence of the individual outside the home is, the lower the corresponding level of social adjustment is. Regarding the external resources, homeless children are confronted with a number of other negative impacts, i.e. economic poverty (Nebbitt et al, 2012); uncertain living situations connected with frequent moving (Swick, 2008); the necessity of socialisation in a specific environment; (often) miserable or missing relationships with families (Nebbitt et al, 2012); nonexistent possibilities to develop a network of relationships outside temporary forms of housing (Swick \& Williams, 2010; Hinton \& Cassel, 2013); their mother's distress (Swick \& Williams, 2010); ostracism, stigmatisation, negative interaction and distrust from the surroundings as a result of their current life situation (Anooshian, 2005; Swick \& Williams, 2010). As for the internal resources, Bassuk (2010) states that it has been established that traumatic experiences and specific stresses connected with being homeless independently lead to a significant number of various symptoms such as depression, anxiety, aggression, and post-traumatic stress. Masten (2012) adds that a significantly higher percentage of homeless children (in comparison with national standards) display an increased level of externalised and internalised educational problems beyond the clinical borderline. Hinton \& Cassel (2013) and Chow, Mistry, \& Melchor (2015) also describe the instability of children without a home in their adjustment in behavioural, social and emotional areas and point out such childrens' difficulties to enter into peer relations as well as their display of some isolated behaviours (see Anooshian, 2005). The above mentioned also becomes evident in the social functioning of homeless children in their school environment. In this context, the researchers have evidenced a lower participation of homeless children in school activities (Chow, Mistry, \& Melchor, 2015). Obradović et al (2009) remark that a lot of the mentioned problems can persist until the childrens' adulthood.

In the context of the above, we consider it important to state that Achenbach \& Rescola (2001) classify social adjustment disorders into the following areas: (1) the occurrence of social issues; (2) violation of norms; (3) the occurrence of aggressive behaviour; (4) withdrawal. According to Reynolds (2001), the social maladjustment can be divided as follows: (1) anti-social behaviour; (2) problems with controlling anger, and partially (3) the occurrence of negative self (e.g. the absence of social interactions and introversion).

\section{Research methodology}

The presented data is partial data from a broader research study aimed at analysing the perception of barriers and accelerators of the reintegration process of homeless mothers - those with an experience of staying in a shelter - into permanent forms of housing. One of the sub-areas that we focused on within the framework of the research was the situation of children in homeless shelters as perceived by their mothers. The subtopic of our research was a question we sought to answer: How do mothers residing with their children in homeless shelters in the city of Ostrava ${ }^{7}$ interpret the social adjustment

\footnotetext{
${ }^{6}$ Hetmánková (2014) states that $92 \%$ of women without a home experienced domestic violence. In two-thirds of these cases the violent offender is the woman's ex-partner, i.e. the children's father. As illustrated by many experts (see e.g. Anooshian, 2005), domestic violence leads to a trauma on both the mother's side and the child's side.

${ }^{7}$ The territory of the city of Ostrava, which is the capital of the Moravian-Silesian region, was selected for the process of deindustrialisation and depopulation of "old" industrial cities that this region has been experiencing (see Illner, 2010). Ostrava represents a highly dynamic and complex environment in terms of eviction from housing. In Ostrava there is the highest number of people living in hostels and socially excluded localities in the Czech Republic (GAC, 2015). The text about the description of social exclusion (2015) lists that Ostrava and the Ostrava region has the fastest growing number of people at risk of social exclusion than any other city or region in the Czech Republic. There are currently 12 homeless shelters in Ostrava, including 5 homeless shelters for a
} 
of their children? In follow up on the determined subtopic of our research, we have selected a qualitative research strategy using the participatory method. The research was based on direct cooperation with two homeless mothers residing, for a long-term basis, in an environment of homeless shelters who participated in all stages of the study from the construction of the half-structured interviews through the collection of data to their analysis. 33 individual interviews with mothers who have experienced life in homeless shelters and 6 focus groups aimed at eliciting content from the same target group were carried out. The informants were selected for research using the method of intentional selection through the institution - homeless shelters in the city of Ostrava and subsequently using snowball sampling. The data obtained was materially substantiated (audio and video recordings were acquired), literally transcribed and analysed using the Constructivist Grounded Theory (Charmaz, 2006). As part of the research, we adhered to the ethical principles defined by the American Psychological Association (APA, 2010).

\section{Research results and their interpretation}

The data obtained was structured into thirteen categories. In the presented partial analysis, we will focus on three basic categories related to the social adjustment of homeless children, namely: (1) the environment of the shelter for the homeless (with elements such as a change in children's behaviour, loss of parental competences, housing shortages, gender imbalances, lack of privacy); (2) the experience of domestic violence (with elements such as children as witnesses to violence, fathers in prison, children as a link between parents, children as the subject of civil litigation), and (3) the educational environment (with elements such as prejudices associated with the shelter institution, learning difficulties, study conditions).

\section{The environment of the homeless shelter}

Some communication partners have reported that residing in a homeless shelter changes the behaviour of their children. "The children are going to backslide here. I used to have well-brought up kids... and now they're nervous all the time, they swear and talk back" (PV2). "It took almost two months before I managed to put the kids back in line since we moved, they were running wild" (KPR30). The environment of the shelter is perceived as negative for raising a women's own children in the sense of group imitation and the escalation of childrens' problematic behaviour.

The communication partners often referred to their concern about children in relation to their stay in a homeless shelter. "It used to be such a decent place here, now it's getting worse. I'm afraid to leave the children alone here. I feel I should constantly keep my eye on them" (KP4). The communication partners also perceived the disruption of their parental competence, namely of their style of childrearing by the rules of the shelter. "I've got four children and they will now be teaching me here how to educate them. I lost a flat, not my ability to raise my children" (KP12). "Here are completely different rules. If I were at home, I'd raise my children in a very different way, we'd sit in peace, etc., but that's not possible here. There's always something you have to do here; this place has a different schedule and regime" (KP13). The above implies that the communication partners feel that the loss of housing and/or housing shortage is confused with their parental competencies. "Here they constantly check on you whether you do this or that well or not. It makes me quite stressed out" (KP18). Some communication partners pointed out that they also considered the fact that their child, especially if they had a son, was missing a male role model, as being "their fault." "Here in this environment where it's all women, it's not easy for my boy, he can't learn what it looks like in a normal family" (KP1). The communication partners also described that they had no other way but to publicly express their emotions in front of their children. "When I came here, I just couldn't stop crying during my first days, the kids saw it, there was no place to hide" (KP2). The need to hide and ventilate one's emotions away from the children is perceived as very strong.

\section{Experience of domestic violence}

Most communication partners who participated in the research had some experience of domestic violence. The most common perpetrator of this violence was their partner (boyfriend). The children

target group of homeless mothers with their children and one for homeless families with a total capacity of 210 people. There are 15 socially excluded localities and 36 hostels (Agency for Social Inclusion, 2015) in Ostrava, while the number of socially excluded localities and hostels has an increased tendency here (GAC, 2015). 
were the direct witnesses of this violence, and in some cases the children themselves were the victims of violence. "I was really scared at the time he pulled out a knife on me..., though he was just waving it. Still, it was a knife, I was really worried about my life and my daughter was at home" (KP6). "So, we started to argue, and he almost strangled me in the kitchen, it even happened before our little daughter's eyes." (KP5). "And so, one day we were just standing with a rucksack, a suitcase and the baby at the door. I had almost nothing with me, he sold everything" (KP19).

It is the children who somehow maintain the boyfriend's presence in the current life of their mother with whom she no longer lives or who is in prison. "I'm in contact with my ex only because of my child, he's in jail now. I write him letters. He's trying to call me all the time. I don't want to be with him anymore, but I write to him because of our children. I share how they are and such" (KP14). There are also dilemmas about how to tell the child what is going on, how the child will endure the school when other children know where their father is and what he does. A boyfriend is in prison, most often from the early age of a child who does not remember their father. "See, I just didn't know what to say, so I said that their father was away in England for work" (KP14).

Children are also mentioned in the narratives of communication partners as a certain way through which the communication partner's feelings can be influenced. "He kept saying he was doing it for the kids, so I tolerated it" (KP11). But children function also as a turning point in the relationship with their mother's boyfriend, whether it is a "fixing of a boyfriend". "When I was pregnant, he completely changed and found himself a job. He quit doing drugs..., but then everything got back into the rut" (KP1) or a final point of the relationship, which is often associated with a possible threat to the child, "He was strangling me in the kitchen in front of my little daughter" (KP5); "I worried about him hurting my little daughter all the time, he pushed her away from him several times, I could no longer take it" (KP4).

In some stories of the communication partners, children are associated with court litigations and the necessity to "fight for them". "A lot of women here have to fight for their kids. I'm happy that I only have one daughter, her dad is in jail, so she's just mine, but as I hear stories like that. What a terrible thing (it is)" (PV1). "Well, I'm engaged in a lawsuit against my ex-husband to get custody of my children, he keeps arguing that I don't have an appropriate home for them, while he's got a flat and such..., I raised them with great care and now he would like to take them" (KP27).

\section{School environment}

Children are also associated with the school and its environment in the narratives of communication partners. In this context, some communication partners verbalised their prejudices that may apply to mothers and children living in a shelter. "We started having problems in school when somebody brought lice into the classroom, they all thought that other children caught it from my son, their parents even called me about it and one mother was screaming at me on the phone, the lice did not come from us though, on the contrary, my daughter brought it from the school here" (KP13). "We're fine at school, my daughter gets good grades, I only had one bad experience when a mobile phone of one child disappeared in the school. It got explained, however, the boy's mother called me to ask if my daughter happened to bring it home with her, maybe she also called and asked other parents, but I felt really insulted at that time, the fact that I live in a homeless shelter does not mean that I'm a thief" (KP15).

The communication partners described some minor conflicts with teachers concerning their children's learning difficulties in relation to their stay in a homeless shelter. "It came to me that the teacher thought that when a child was living in a homeless helter, they needed to be dumb and would be hurting other children. I felt like the teacher was biased against my son, he kept bringing home the worst grades. I went to school and asked why only my son brings home the worst grades, in the end it seemed like a misunderstanding and he started receiving some extra tutoring" (KP15).

One of the communication partners described her daughter as having experienced bullying in her class which she associated with staying in a shelter. "Well, when the kids from her class found out that my daughter was from a homeless shelter, they followed her home, shouted at her and called her names, they had been mocking her in the class previously, she obviously didn't have any expensive mobile phones and other trinkets like them, but other than that she was always dressed nice and clean..., we then had to address it with her class teacher and school counsellor, they told us that because it (the 
calling her names) happened out of school, they couldn't do anything. The kids then had a lecture about bullying in school though" (KP14).

In relation to school, the communication partners talked about insufficient learning conditions for their children. "What is stupid in the shelter is that there is just a little room here. Moreover, the school now wants children to search for different things on the Internet, kids also use Facebook for communication a lot, so our kids are often out of touch, also when I think about it, there is not a proper desk here. I mean some quiet place where the kids could do their homework and study, yeah, there're no good conditions for it" (PV1).

\section{Conclusion and implication for social work with children living in shelters}

The above presented data describes the situation of children in homeless shelters through the optics of their mothers. Children living in a shelter have been confronted with the necessity of socialization in a specific environment (Nebbitt et al, 2012) that the communication partners described as a negative environment for raising children (the environment that changes the behaviour of children in a negative sense), as an environment changing the parenting style in relation to their children and an environment where they worry about their children. It is also an environment characterised by the following phenomena: a mother's distress and her inability to hide it (Swick \& Williams, 2010), stigmatisation, negative interaction and distrust from the environment connected to their current life situation (Swick \& Williams, 2010; Anooshian, 2005), learning difficulties at school (Masten, 2012), which are in direct interaction with the lack of study space. The experience of domestic violence along with the homelessness situation is certainly a very powerful source of stress for children too (similarly see Bassuk, 2010). In the context of the above we can state that social adjustment is one of the areas which plays an important role not only in the process of socialization of minor children.

In relation to the above, the critical reflexivity in social work together with the concept of social adjustment with children from homeless shelters also needs to be emphasised. Critical reflexivity in this context is understood in accordance with D'Cruz et al (2007) as a form of destabilisation or the questioning of what we consider to be knowledge and the daily defence of knowledge. Reflexivity is therefore a process of looking from the outside at social and cultural artefacts and forms of thinking that saturate the practice of social work and the questioning and challenging processes that give sense to the world. In the context of social work with children from homeless shelters using the social adjustment concept, it is necessary to reflect social adjustment through the optics of the ecological model, which involves the interaction of external and internal causes of possible problems with social adjustment. Within this model, it is important to approach the behaviour of children as a certain continuum that is highly influenced by the context in which it is experienced, and not as an individual pathology (see also Levendosky \& Graham-Bermann, 2001). Within the interaction model, it must also be taken into account that the child's identity is shaped not only by the static conditions of the external environment but also by the way the external environment approaches the child and how it responds to his/her behaviour. Therefore, the "ego" of a child can be considered as being forged in a social interaction. If these reactions are negative, we can assume that they will negatively affect the child's "ego" and thus his/her future behaviour towards the environment (see also Anooshian, 2005). The use of a critically reflexive approach to social work with children from shelters for the homeless can thus lead not only to recognition of how one's thinking may be restrictive and thus limit one's options for practice, but also to a deeper understanding of the children's life situation, to a reframing of the idea of power, and through which social workers will be able to work using empowerment methods, and to an emphasis on agency (Fook \& Askeland, 2006; Fook, 2016) as well as to the creation of more inclusive and less biased practices (Fazio, 2009; Jones, 2010).

\section{Acknowledgement}

This study was published with support of the Czech Science Foundation GA ČR 18-10233S Social Adjustment of Homeless Children with Domestic Violence Experience in the Territory of the City of Ostrava.

\section{References}

Achenbach, T. M., \& Rescorla, L. A. (2001). Manual for the ASEBA school age forms and profiles. Burlington, V. T: University of Vermont, Research Centre for Children, Youth and Families.

American Psychological Association (APA). (2010). Ethical principles of psychologists and code of conduct. Retrieved from http://www.apa.org/ethics/code/ 
Anooshian, L. J. (2005). Violence and aggression in the lives of homeless children: A review. Aggression and Violent Behavior, 20(6), 373-387.

Bassuk, E. L. (2010). Ending child homelessness in America. American Journal of Orthopsychiatry, 80(4), 496-504.

Charmaz, K. (2006). Constructing Grounded Theory: A practical guide through qualitative analysis. London: Sage.

Chow, K. A., Mistry, R. S., \& Melchor, V. L. (2015). Homelessness in the elementary school classroom: social and emotional consequences. International Journal of Qualitative Studies in Education, 28(6), 641-662.

D'Cruz, H. et al. (2007). Reflexivity, its meanings and relevance for social work: A critical review of the literature. The British Journal of Social Work, 37(1), 73-90. doi: https://doi.org/10.1093/bjsw/bcl001

Fazio, X. (2009). Teacher development using group discussion and reflection. Reflective Practice, 10(4), 529-541.

Fook, J. (2016). Researching critical reflection. Multidisciplinary perspectives. NY: Routledge.

Fook, J. \& Askeland, G. (2006). The 'critical' in critical reflection. In S. White, J. Fook \& F. Gardner (Eds.), Critical reflection in health and social care (pp. 40-54). Buckingham: Open University Press.

GAC. (2015). Analýza sociálně vyloučených lokalit v ČR [Analysis of socially excluded localities in the Czech Republic]. Retrieved from http://www.gac.cz/userfiles/Analyza_socialne_vyloucenych_lokalit_GAC.pdf

Hetmánková, R. (2014). Ženy bez domova: Identita, strategie a bezpečný prostor [Homeless women: Identity, strategy and safe area]. Gender, rovné př́ležitosti, výzkum. 15(1), 81-84.

Hinton, S., \& Cassel, D. (2013). Exploring the lived experiences of homeless families with young children. Early Childhood Education Journal, 41(6), 457-463.

Hirschfeld, R. M. A., Montgomery, S. A., \& Keller, M. B. (2000). Social functioning in depression: A review. Journal of Clinical Psychiatry, 61(4), 268-275.

Illner, M. (2010). Deindustrializace průmyslových měst - projevy, př́činy, důsledky a strategie revitalizace [Deindustrialization of industrial cities - manifestations, causes, consequences and strategies of revitalization]. In L. Hruška et al. (2010). Industriální město v postindustriální společnosti I. [Industrial City in Post-Industrial Society I.]. (pp. 9-20). Ostrava: VŠ́B - Technická univerzita Ostrava.

Jones, C. (2010). Voices from the front line: State social workers and new labour. British Journal of Social Work, $31,547-$ 562

Levendosky, A. A., \& Graham-Bermann, S. A. (2001). Parenting in battered women: The effects of domestic violence on women and their children. Journal of Family Violence, 16(2), 171-192.

Lipschitz-Elhawi, R., \& Izhaky, H. (2005). Social support, mastery, self-esteem and individual adjustment among at-risk youth. Child and Youth Care forum, 34(5), 329-346.

Masten, A. S. (2012). Risk and resilience in the educational success of homeless and highly mobile children: Introduction to the special section. Educational Researcher, 41(9), 363-365.

Nebbitt, V. E., Lombe, M., Yu, M., \& Vaugnh, M. G. (2012). Ecological correlates of substance use in African American adolescents living in public housing communities: Assessing the moderating effects of social cohesion. Children and Youth Services Review, 34(2), 338-347.

Nilson, D. (2007). Adapting coping theory to explain the concept of adjustment. Social work in Health Care, 45(2), 1-20.

Novotný, S. J. (2015). Zdroje resilience a problémy s přizpůsobením u dospívajících [Sources of resilience and adaptation problems in adolescents]. Ostrava: Ostravská univerzita.

Obradović, J., Long, J., Cutuli, J. J., Chan, Ch., Hinz, E., Heistad, D., \& Masten, A. S. (2009). Academic achievement of homeless and highly mobile children in an urban school district: Longitudinal evidence on risk, growth, and resilience. Development and Psychopathology, 21(2), 493-518.

Ponizovsky, A. M., Levov, K., Schultz, Y., \& Radomislensky, I. (2011). Attachment insecurity and psychological resources associated with adjustment disorders. American Journal of Ortopsychiatry, 81(2), 265-276.

Powell, T. L. (2012). The impact of being homeless on young children and their families. NHSA Dialog, 15(2), 221-228.

Reiter, S., \& Lapidot-Lefler, N. (2007). Bullying among special education students with intellectual disabilities: Differences in social adjustment and social skills. Intellectual and Developmental Disabilities, 45(3), 174-181.

Reynolds W. M. (2001). Reynolds Adolescent Adjustment Screening Inventory (RAASI). Odessa, FL: Psychological Assessment Resources.

Salvation Army. (2016). Dotazníkové šetření uživatelů azylových domů a domů pro matky s dětmi [Questionnaire survey of users of shelters and houses for mothers with children]. Praha: Armáda Spásy.

Swick, K. J. (2008). The dynamics of violence and homelessness among young families. Early Childhood Education Journal, $36(1), 81-85$

Swick, K. J., \& Williams, R. D. (2010). The voices of single parent mothers who are homeless: Implications for early childhood professionals. Early Childhood Educational Journal, 38(1), 49-55.

United States Conference of Mayors (2006). A status report on hunger and homelessness in America's cities. Retrieved from http://usmayors.org/hungersurvey/2006/report06.pdf 